\title{
RETRACTED: EXSOLUTION LAMELLAE IN ORTHOPYROXENE OF LHERZOLITE FROM THE PAUZA ULTRAMAFIC ROCKS, NE IRAQ: EVIDENCE OF DEEP MANTLE SIGNATURE IN THE ZAGROS SUTURE ZONE
}

\author{
Yousif Osman Mohammad ${ }^{1}$--- Nabaz Rashid Hama Aziz ${ }^{2}$ \\ ${ }^{1,2}$ Department of Geology, University of Sulaimani, Iraqi Kurdistan region
}

\begin{abstract}
The Pauza ultramafic body is part of Upper Cretaceous Ophiolitic massifs of the Zagros Suture Zone, NE Iraq. The present study reveals evidence of Ultra-high pressure (UHP), and deep mantle signature of these peridotites in the Zagros Suture Zone throughout the observation of backscattered images and micro analyses which have been performed on orthopyroxen crystals in lherzolite of Pauza ultramafic rocks.Theorthopyroxen shows abundant exsolution lamellae of coarse unevenly distributed clinopyroxene coupled with the submicron uniformly distributed needles of Cr-spinel. The observed clusters of Opx-CpxSpl represent the decompression products of pyrope-rich garnet produced as a result of the transition from ultra-high pressure garnet peridotite to low-pressure spinel peridotite (LP). Neoblastic olivine (Fo9-9s) with abundant multi-form Cr-spinel inclusions occurs as a fine-grained aggregate around orthopyroxene, whereas coarse olivine ( Fog-91 $\left._{1}\right)$ free from chromian-spinel is found in matrix. The similarity of the Cr-spinel lamellae orientations in both olivine and orthopyroxene, moreover, the enrichments of both Cr and $\mathrm{Fe} e^{s+}$ in the Cr-spinel inclusions in neoblastic olivine relative to Cr-spinel lamellae in orthopyroxene, suggest that spinel inclusions in olivine have been derived from former Cr-spinel lamellae in orthopyroxene. Neoblastic olivine is formed by reaction of silica-poor ascending melt and orthopyroxene. It is inferred that the olivines with multi-form spinel inclusions has been formed by incongruent melting of pre-existing spinel lamellae-rich orthopyroxene.
\end{abstract}

Keywords: Spinel lamellae, Pauza ultramafic body, Zagros suture zone, Lherzolite, Replacive olivine.

Received: 9 September 2013/ Revised: 25 October 2013/ Accepted: 29 October 2013/ Published: 2 November 2013

\section{INTRODUCTION}

The widespread existence of garnet peridotite within ultrahigh-pressure metamorphic (UHPM) orogenic belts makes garnet peridotite an important window to the geodynamic 
processes of continental subduction, collision, exhumation and crustal-mantle interaction. Although micro-structural features of mineral phases may be changed several times during subduction and exhumation of the rocks, nevertheless, they remain the most powerful witnesses of possible phase. Accordingly, in recent years, spinel exsolution lamellae micro-structures in garnet peridotites are interpreted as evidence that this peridotite body has experienced ultrahigh-pressure metamorphic conditions due to decompression, cooling and oxidation (Song et al., 2009b). In this contribution we report on the occurrence of a rare porphyroblast of orthopyroxene that shows typical hosted exsolution lamellae of clinopyroxene and $\mathrm{Cr}$-spinel in garnet lherzoliteof the Pauza Complex. Backscattered images and microanalysis are presented that further support ultra-deep subduction of the peridotite and give eyidence of Ultra-high pressure (UHP) signature of these peridotites, rather than the previous sepentinized abyssal peridotite origin of the ultramafic part of ophiolite within the Iraqi Zagros Suture Zone.

\section{GEOLOGICAL SETTING}

The Zagros Suture Zone (ZSZ) extends in a NW-SE direction and crop out in a $5-7 \mathrm{~km}$ wide and approximately $1,500 \mathrm{~km}$ in length along the Iraqi-Iranian-Turkish borders (Fig. 1). This still-active belt is mainly related to the opening and closure of the NeoTethyan oceanic basin and results from the collision of the Arabian and Eurasian plates during Cenozoic times (Berberian et al., 1982).The Zagros Suture Zone is one of the youngest continental collision belts within the Alpine-Himalayan orogenic system (Rico et al., 1977). The complete late Cretaceous and Tertiary history of this protracted collision is still debated. Orogenic processes started with the tectonic emplacement of ophiolitic slices over the NE Arabian passive margin, from SE Turkey, NE Iraq, to Oman, at the end of Cretaceous times. The Zagros Suture Zone of northeastern Iraq and their ophiolite components is a spectacular example of a young Tertiary orogenic event and of earlier obduction/subduction processes.Four main metamorphosed alpine-type peridotites are disseminated along this zone; they occur as relict ultramafic bodies with highly sheared basal serpentinites(Aziz et al., 2011) forming the main dismembered Upper Cretaceous (Aswad and Elias, 1988)Ophiolite massifs of the Zagros Suture Zone. The Pauaz ultramafic rocks which occupy southern and western margin of the Bulfat complex are parts of the dismembered Iraqi Zagros Suture Zone ophiolite. It consists of basic rock introduced to the poly-metamorphosed rocks of the Gimo Group (Fig. 1), forming about $4 \%$ the area of the Bulfat igneous complex. The ultramafic rocks show layering, which could be inherited from primary igneous layering such as seen in layered cumulate, or could be of metamorphic in origin. The Pauza ultramafic body is about $1 \mathrm{~km}$ thick and $1.5-2 \mathrm{~km}$ wide. Both lower and upper contacts with adjoining strata are tectonic, with typical tectonic breccia (Hamasalh, 2004). Dunite occurs as podiform $(40-30 \mathrm{~cm}$ in diameter) with spheroidal weathering or tabular sills in the upper part of the Pauza ultramafic body. The lower part of the body consists of harzburgite and lherzolite. The Pauza ultramafic body is cut by centimeter scales sills and veins of pyroxenite and hornblendite with typical flow textures (Fig.2A). 
Fig-1. Geological map of Bulfat complex, NE Iraq

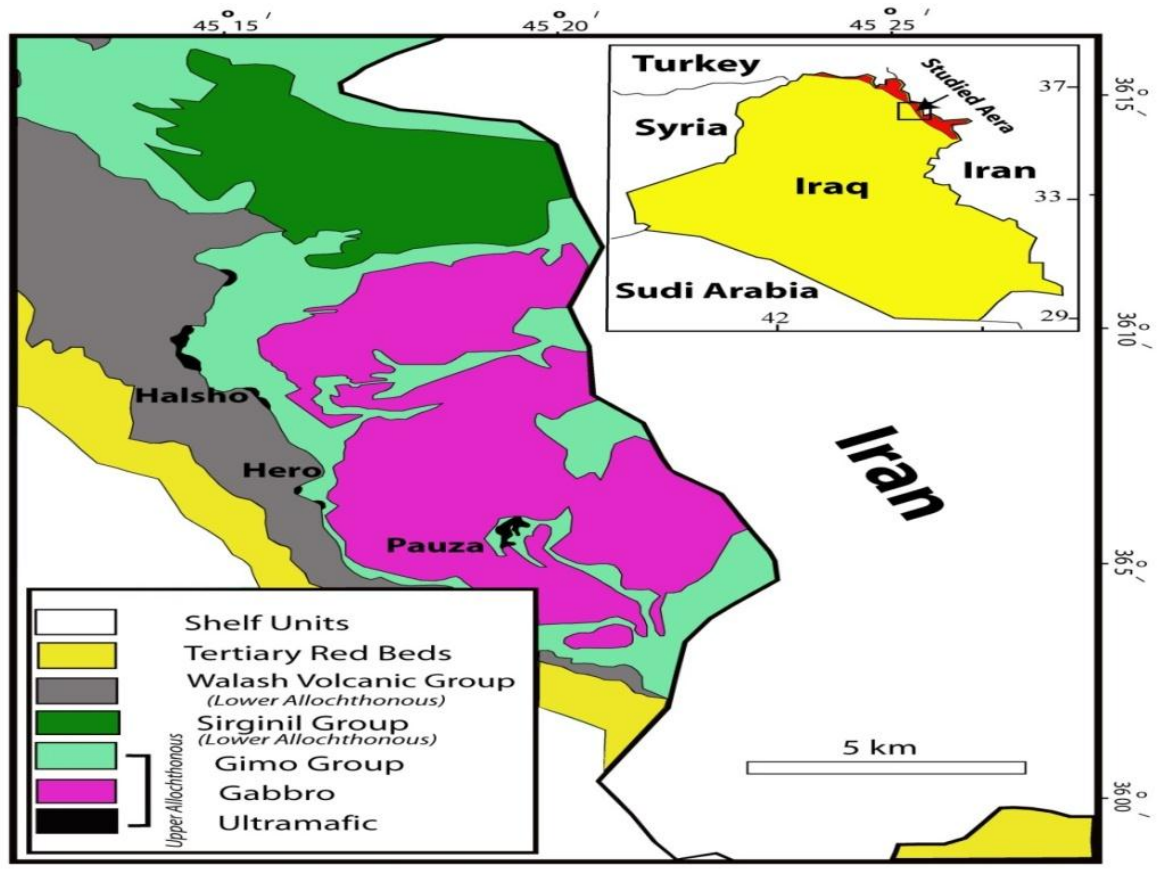

\section{MATERIALS AND METHODS}

EDS analyses of the main rock-forming minerals were carried out with a JEOL-840A scanning electron microscope, equipped with an energy dispersive detector analytical system (Link ISIS series L200I-S) at Osaka Prefecture University/Japan. The analyses were performed using $15 \mathrm{kV}$ accelerating yoltage and $0.5 \mathrm{nA}$ current beam. Suitable natural and synthetic silicate oxides were used as standards for calibration. The ZAF method was employed for corrections. Total iron was measured as $\mathrm{FeO}$ and recalculated by using ideal stoichiometry to give the $\mathrm{FeO}$ and $\mathrm{Fe}_{2} \mathrm{O}_{3}$ value. Electron microanalyses of minerals from a lherzolite are listed in Table 1.

\section{RESULTS}

\subsection{Petrography}

Lherzolite is the less abundant rock type compared to harzburgite in the Pauza ultramafic rocks and consists of olivine, orthopyroxene and a lesser amount of clinopyroxene and spinel. The modal abundances of olivine is 70-80 vol. \%, orthopyroxene 15-20 vol. \%, clinopyroxene 5-8 vol. $\%$ and spinel 5 vol. \%. Clinopyroxene is rare and occurs either as exsolution lamellae in orthopyroxeneoraseuhedral crystal in matrix. Small amounts of serpentinite, chlorite and opaque minerals were also observed. EDS microanalysis reveal accessory pentlandite, Skaergaardite and native copper are dispersed in the rock. In addition to partial serpentinization of the rock, the veins of serpentine and Fe-oxides are common throughout the rock on the thin section scale . Most of minerals display structures of plastic deformation such as undulose extinction, strain lamellae, kink bands, rotation, shearing, and recrystallization, all typical deformation features of alpine-type upper mantle peridotites (Evans, 1977). 
Olivine is found as porphyroclasts $(<2 \mathrm{~mm})$ and smaller polygonal neoblasts $(\approx 0.2 \mathrm{~mm})$ with predominant $120^{\circ}$ triple junctions around orthopyroxene. Patches of fine to coarse-grained olivine can locally completely replace orthopyroxeneporphyroclasts, forming mellimetricpodiformdunite (Fig.2B).

The grain size of olivine is remarkably variable. Moreover, detailed observation under the optical microscope and secondary electron images showed marked differences in the grain shape, presenceor absence of Cr-spinel inclusions and deformation patterns of olivine. Accordingly, olivine grains can be classified as the olivines grains of the older generation (mantle olivine), that occur as anhedral coarse-grained crystal ( $<2 \mathrm{~mm}$ across) exhibiting deformational features like kink bands and strain lamellae and (2) new generation neoblastic olivine usually found as aggregates of fine to medium-grained crystals ( $0.1 \mathrm{~mm}-0.4 \mathrm{~mm}$ ) around or within orthopyroxeneporphyroclast. The former is devoid of Cr-spinel inclusions. In the later some neobalsts contain swarm of heterogeneously distributed multi-form $\mathrm{Cr}$-spinel inclusions ranging in shape from rounded, oval and lamellae forms (Figs. 3 A\&B).

Fig-2.Photomicrograph of (A) hornblendite with typical flow texture from Pauza massif. (B) Mellimetricpodiformdunite inPauza massif. Abbreviation after (Kretz, 1983).

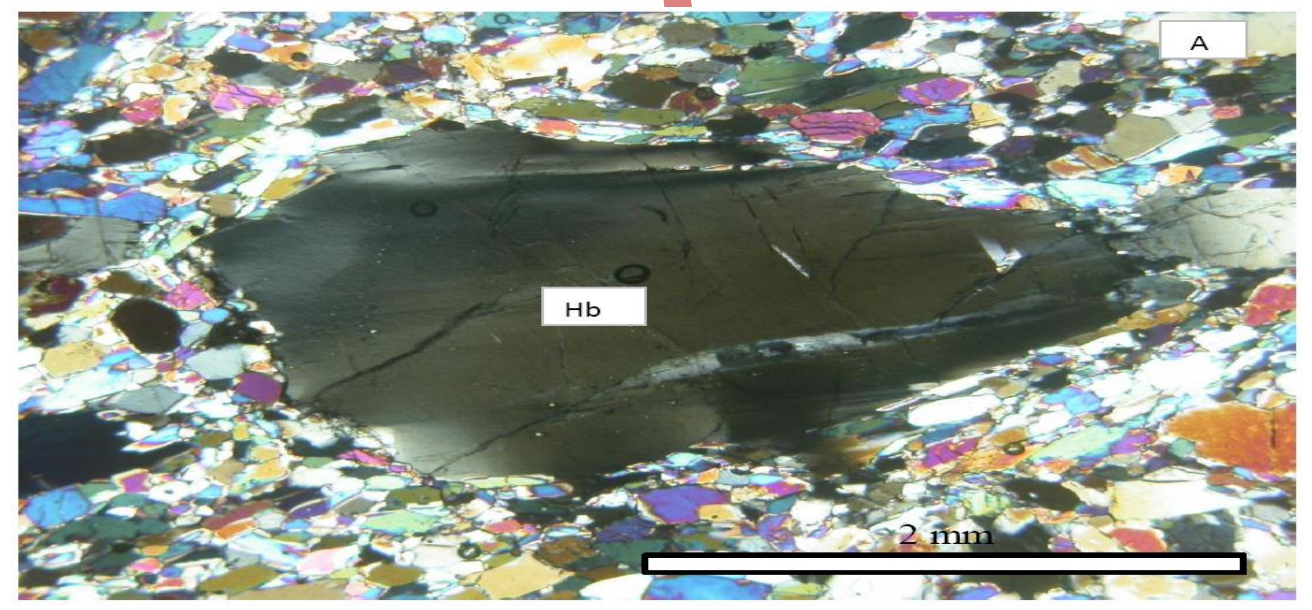

4

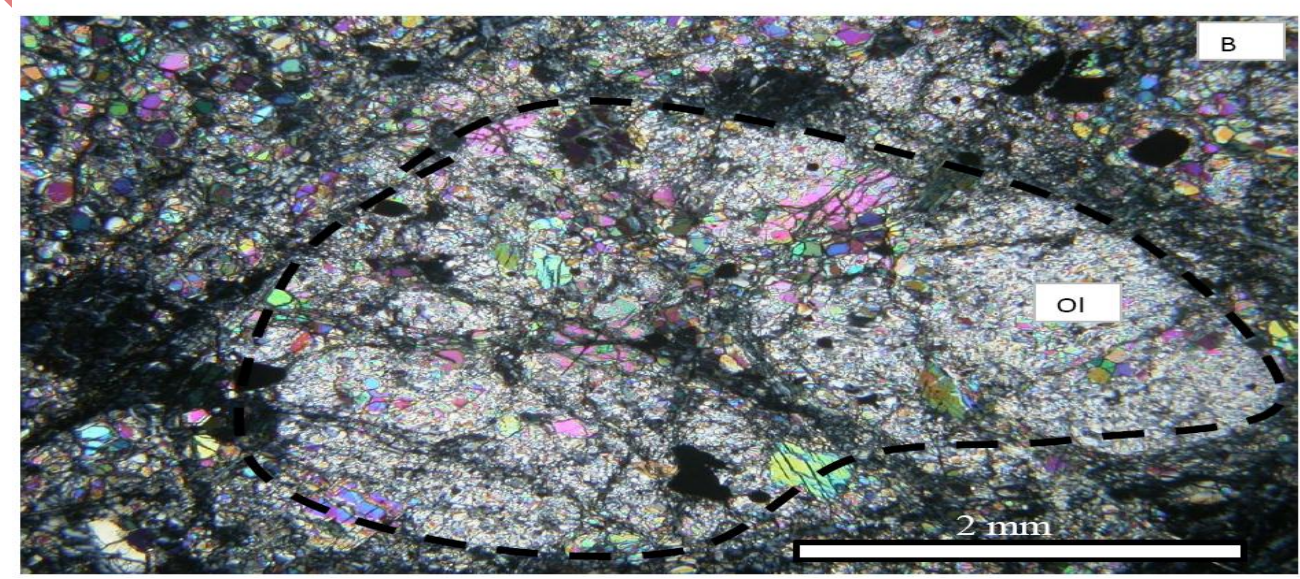


Fig-3.Photomicrograph of lherzolite, (A) and (B) olivine with both spinel lamellae and octahedral inclusions along the orthpyroxene rim.Abbrevations :Cpx , clinopyroxene, Ol, Olivine. Abbreviations after (Kretz, 1983).
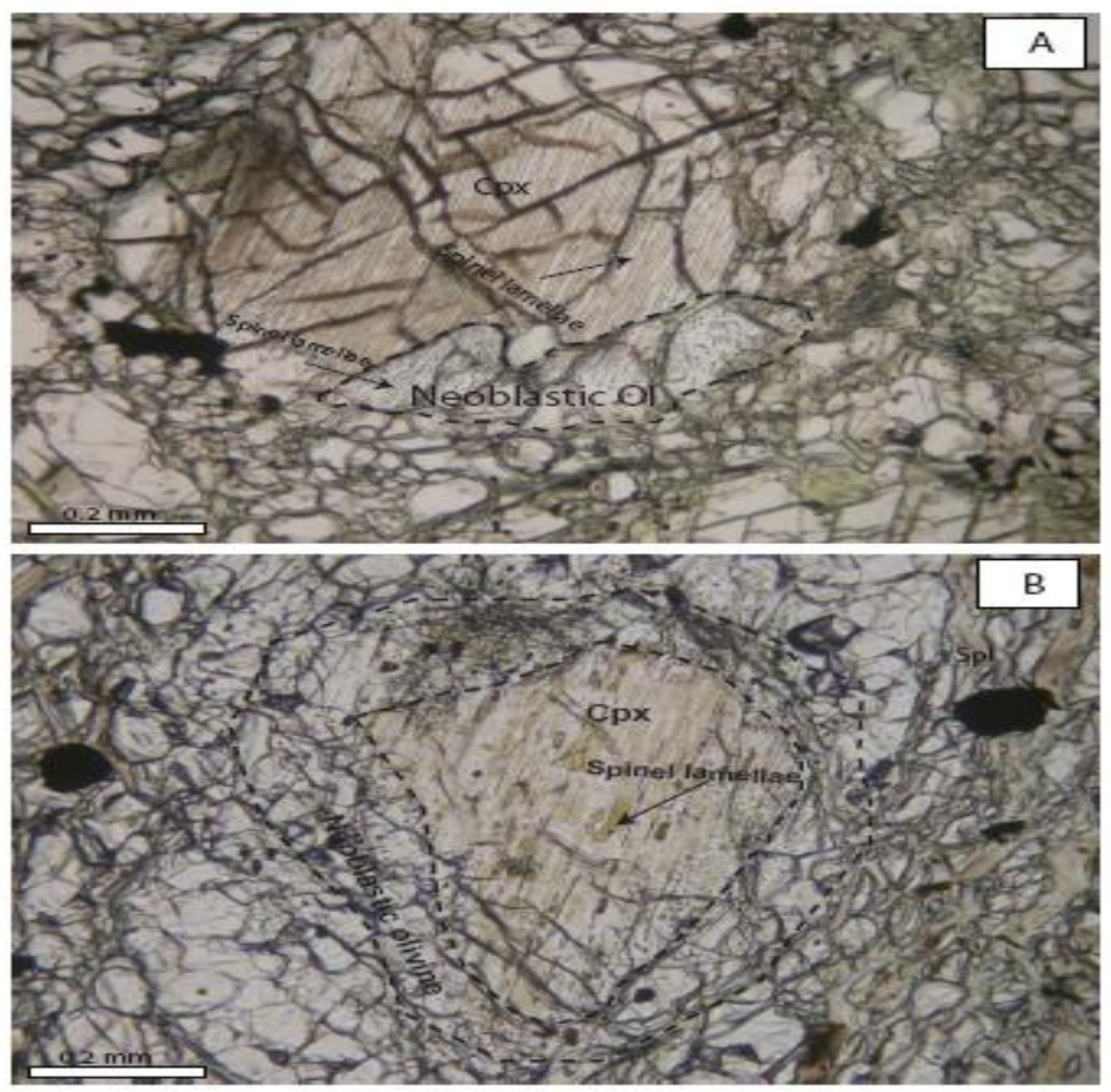

Subhedralorthopyroxeneporphyroclasts $(1-2 \mathrm{~mm})$ with exsolution lamellae of spinel and clinopyroxene are dominant (Figs. 4A and 3B). Orthopyroxene with one set of Cr-spinel exsolution lamellae are common, in some orthopyroxene crystal two perpendicular set of Crspinel lamellae are observed. The length and width of spinel lamellae is variable, but the distance between adjacent lamellae in nearly constant. Cr-spinel lamellae in orthopyroxene are up to $5 \mu \mathrm{m}$ wide and $25 \mu \mathrm{m}$ length, and are homogenously distributed within the host othopyroxene (Figs.3C and $3 \mathrm{D})$

Fig-4. (A) Back-scattered image at boundary between orthopyroxene and olivine, both comprise spinel exsolution lamellae, (B) Exsolution lamellae of spinel and clinopyroxene in orthopyroxene (C) Subhedralorthpyroxene with spinel exsolution lamellae. (D Back-scattered image of the orthopyroxene containing exsolution lamellae of both spinel and clinopyroxene. Abbreviations: Ol, olivine; CPX, clinopyroxene; OPX, orthopyroxene, Spl, spinel. Abbrevations after (Kretz, 1983). 

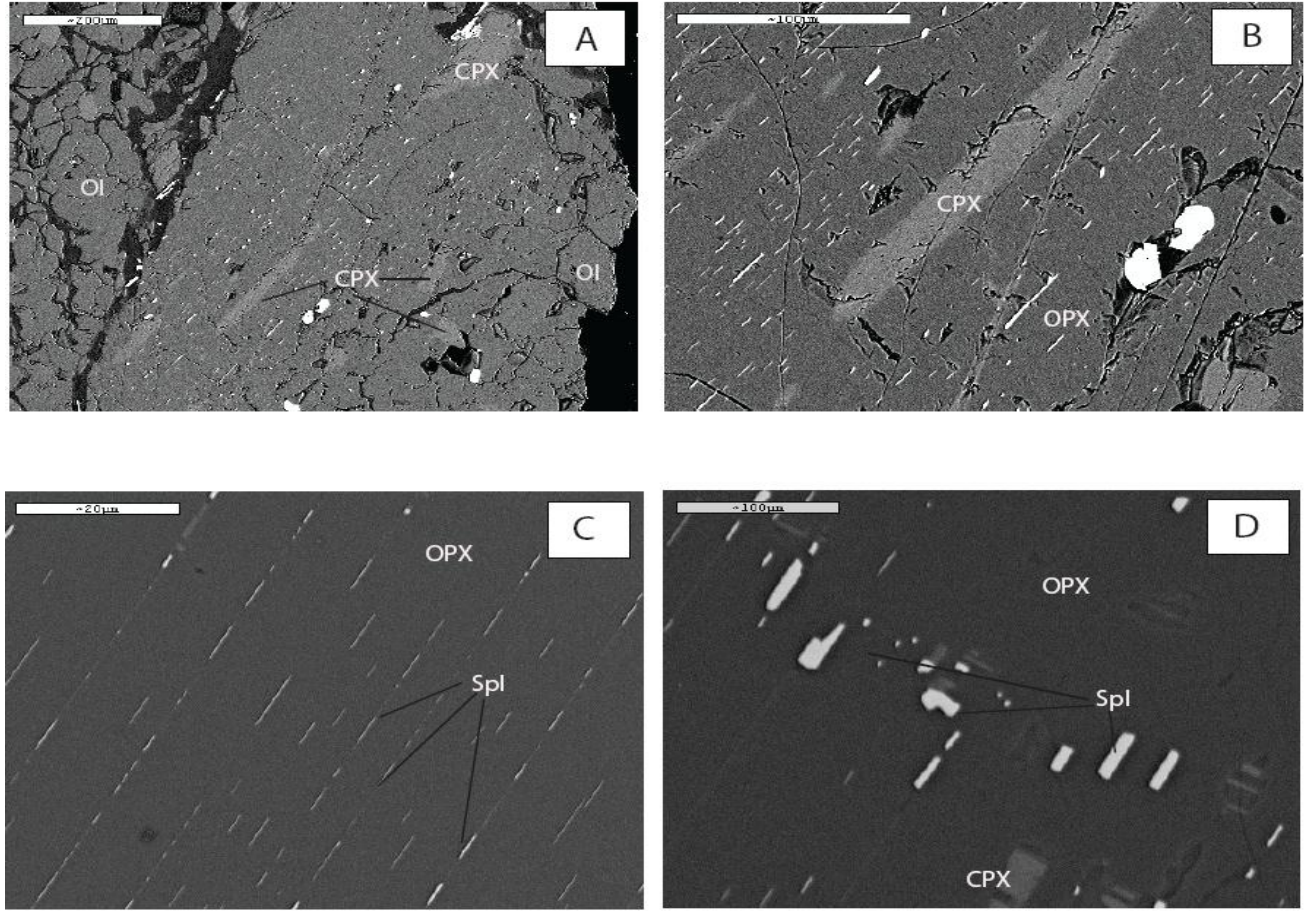

Clinopyroxene usually occurs either in the form of thick lamellae in orthopyroxene or as subhedral fine-grained around orthopyroxene and as euhedral crystals in the matrix (Figs. 4A and 4B). Garnet only observed along some cleavage traces of clinopyroxene (Fig. 5)

Fig-5.Backscattered image of clinopyroxene hosting pyrope rich garnet along the cleavage plane in lherzolite from Pauza massif.Abbrevation after (Kretz, 1983).

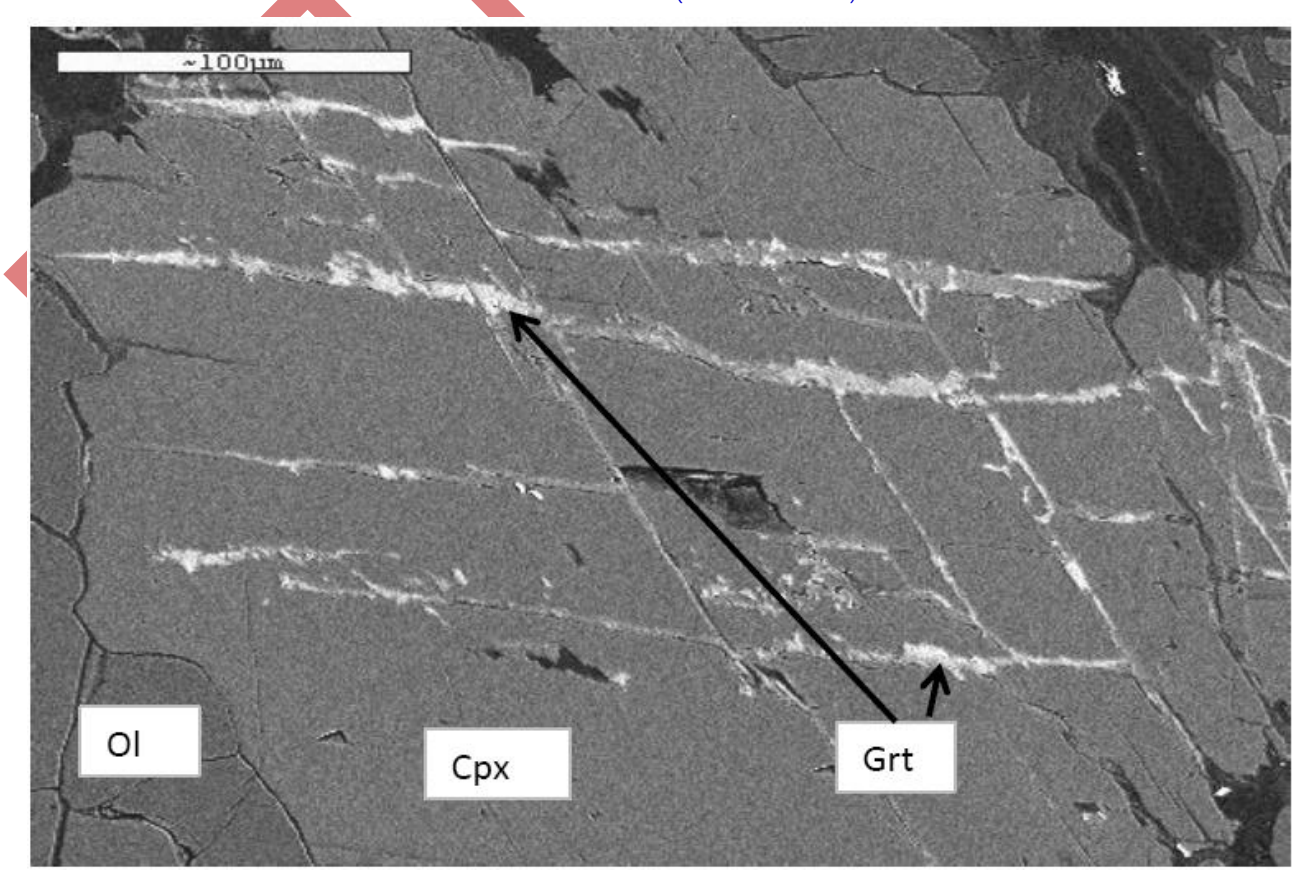


Holly-leaf Cr-spinel is reported in matrix as grains $(<3 \mathrm{~mm}$ in diameter) with lobate boundaries, usually veined and surrounded by a rim of syn-serpeninization magnetite. Cr-spinel lamellae, are documented in both olivine and orthopyroxene (Figs. 3E ). Spinel inclusions in olivine differs from those in Opx in terms of their dimensions and chemistry (Fig.3D).

\subsection{Mineral chemistry}

\subsubsection{Olivine}

Mantle olivine is homogeneous in composition and has a composition of 90-91 mol. \% Fo with 0.45 wt. $\%$ of $\mathrm{NiO}$, and 0.06 wt. $\%$ of $\mathrm{Cr}_{2} \mathrm{O}_{3}$. These values are similar to normal mantle olivine (Takahashi, 1986). Compositional variation at thin section scale is generally small, normally less than $1 \mathrm{~mol} \%$ Fo.Neoblastic olivine is homogenous in composition and has a composition of 91-92 mol. \% Fo with 0.3 wt. \% of NiO, and more than 0.01 wt.\% of $\mathrm{Cr}_{2} \mathrm{O}_{3}$. Compositional variation at thin section scale is generally very small, normally less than $0.5 \mathrm{~mol} \%$ Fo. These values are resembling to those of replacive olivine in harzburgite (Kubo, 2002).

Table-1.Representative electron microanalyses of minerals from the lherzolite of the Pauza Ultramafic rock.

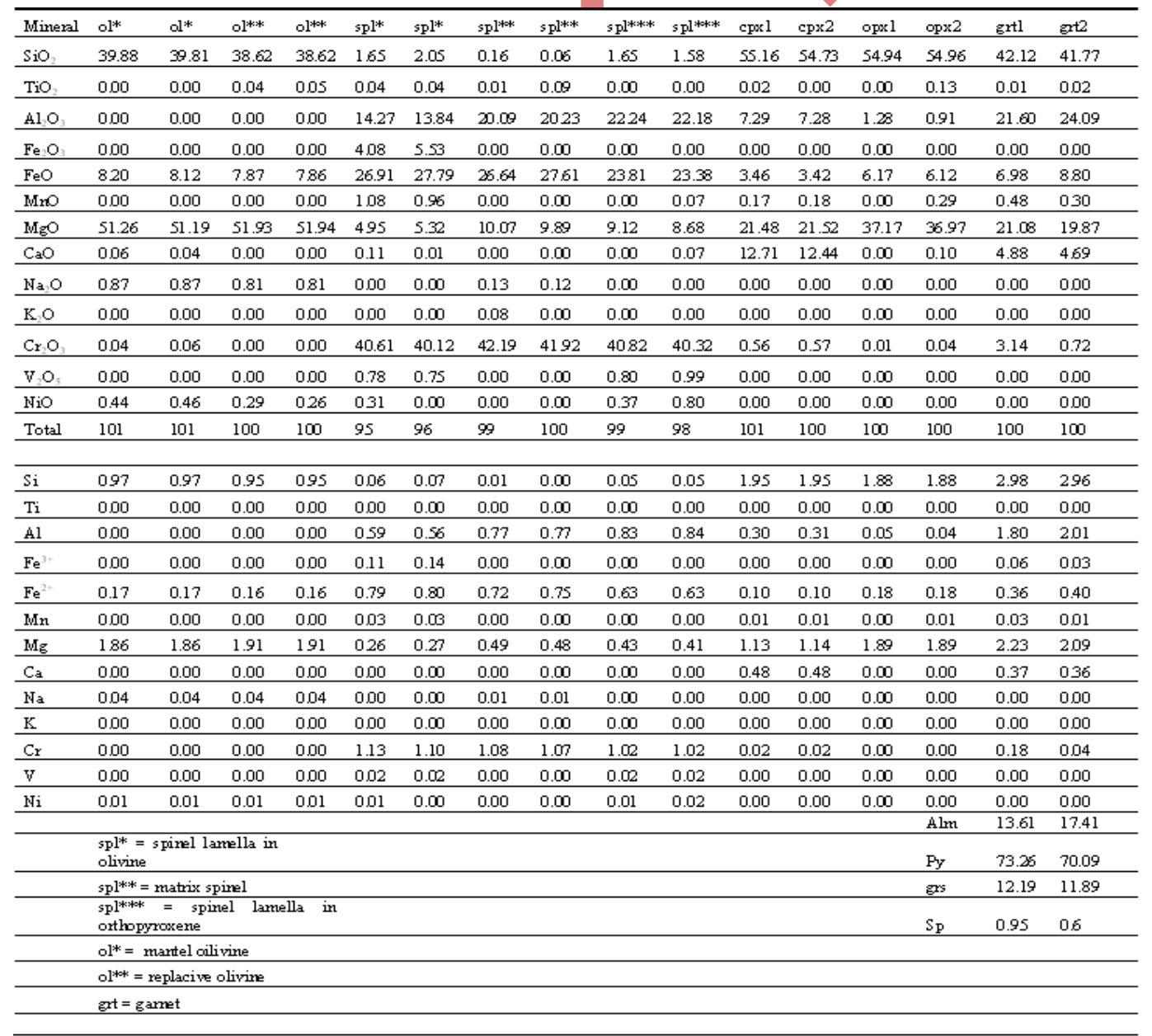




\subsection{Orthopyroxene}

Orthopyroxene is enstatite with $\mathrm{Mg}$-number 91-92 (Fig. 6). The $\mathrm{Al}_{2} \mathrm{O}_{3}$ varies between 0.96 and 1.3 wt. \%, with very low $\mathrm{CaO}$ and $\mathrm{TiO}_{2}$ contents $(<0.1$ wt. $\%$ and $<0.05$ wt. \%, respectively). These chemical features of orthopyroxene are similar to those reported from less fertile spinel peridotites, garnet peridotitesin Kapvaalkimberlites in south Afirac (Franz and Wirth, 2000; Grégoire et al., 2005) and in garnet peridotites from the Qaidam ultrahigh-pressure belt, northern Tibetan Plateau, NW-China (Song et al., 2004).

Fig-6. Composition of pyroxene in Wo-En-Fs diagram, yellow solid squares are compositions of orthopyroxene, green stares are compositions of clinopyroxene lamellae.

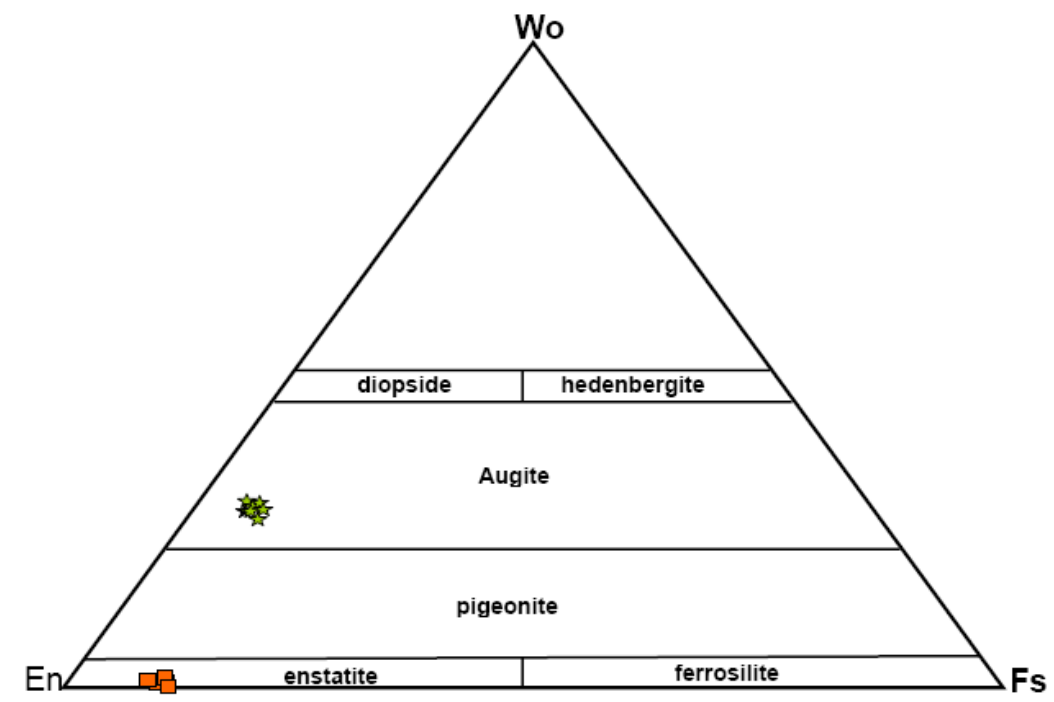

\subsection{Clinopyroxene}

Clinopyroxene, mainly found as exsolution lamellae in orthopyroxene, is aluminachromianaguite (Fig. 6), with Mg-number ranging from 93 to 94. It contains 6 to 8 wt. \% of $\mathrm{Al}_{2} \mathrm{O}_{3}, \mathrm{Cr}_{2} \mathrm{O}_{3}$ varies from 0.5 to 1.0 wt. \%, and very low $\mathrm{TiO}_{2}(>0.02 \mathrm{Wt} \%$ ). Similar clinopyroxene are reported from garnet peridotites in Kapvaalkimberlites (Zhang et al., 2001; Grégoire et al., 2005).

\subsection{Cr-spinel}

Spinel in matrix is $\mathrm{Mg}-\mathrm{Al}$ chromite, with $\mathrm{Cr}-\#$ (100 atomic $\mathrm{Cr} / \mathrm{Cr}+\mathrm{Al})$ ranging from 57 to 58 and low $\mathrm{TiO}_{2}$ content below 0.2 wt. \%. Spinel lamellae in orthopyroxene has Cr-\# ranging from 47 to 53, and $\mathrm{MnO}$ contents is low (0.5 wt \%). Cr-\# of spinel inclusions in olivine ranges from 65 to 67 . In addition it has higher $\mathrm{MnO}$ and $\mathrm{SiO}_{2}$ content (1 wt. \%) relative to spinel lamellae in orthopyroxene. 


\subsection{Garnet}

The garnet composition is relatively homogeneous with chemical formula $\mathrm{Am}_{13-17} \mathrm{Pyp}_{70-}$ ${ }_{73} \mathrm{Grs}_{12-11} \mathrm{Spe}_{0.6-0.9}$. In the Grs-Prp-Alm+Sps ternary diagram (Fig.7), representative points of sample PZ 12 mainly plot within the A-type eclogite field (Coleman et al., 1965).

Fig-7. Garnet compositions plotted as mole percentpyrope-grossular-almandine.

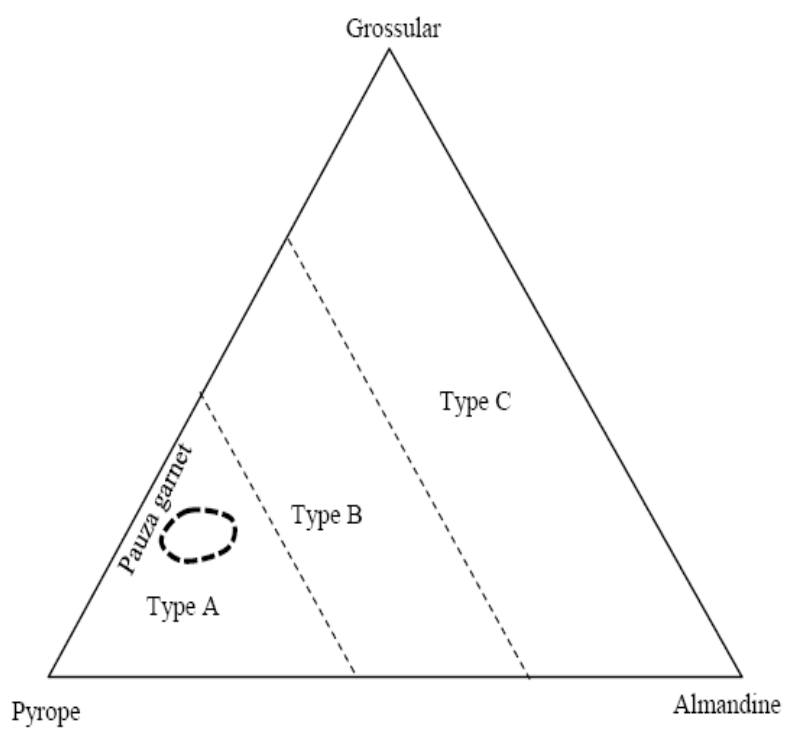

\section{DISCUSSION}

\subsection{Condition of lamellae formations}

\subsubsection{Exsolutions in orthopyroxene}

The cluster of Spl-Cpx-Opx in a single grain recorded either as wormy like randomly intergrowth cluster referred as symplecite or as crystallographic control intergrowth with systematic distribution referred as exsolutions lamellae.

Spinel-bearing symplectite around garnet (i.e. kelyphite) is a common feature of many garnetperidotites. Kelyphite formation is related to decompression of garnet-peridotites from both ultrahigh pressure metamorphic terranes and kimberlite xenoliths (Godard and Martin, 2000). Kelyphite is an intergrowth texture of minerals, including two pyroxenes, spinel and occasionally amphibole. It records the transition from ultra-high pressure garnet peridotite to low-pressure (LP) spinel peridotite with continuous exhumation and decompression. At the garnet spinel transition pyrope-rich garnet is replaced by Opx $+\mathrm{Cpx}+\mathrm{Spl}$ at $\leq 3.0 \mathrm{GPa}$ by the decomposition reaction.

Parallel lamellae of spinel and clinopyroxen in orthopyroxene most likely resulted from exsolution of pyrope-rich garnet megacrysts (Godard and Martin, 2000)or Al-Ca rich Opx (Nida, 1984). The exsolution can be ascribed o the following reactions in the $\mathrm{CaO}-\mathrm{MgO}-\mathrm{FeO}-\mathrm{Al}_{2} \mathrm{O}_{3}-$ $\mathrm{SiO}_{2}-\mathrm{Cr}_{2} \mathrm{O}_{3}$ (CMFASCr) system (Godard and Martin, 2000).

$[\mathrm{Mg} ; \mathrm{Fe} ; \mathrm{Ca}]_{3}(\mathrm{Al} ; \mathrm{Cr})_{2} \mathrm{Si}_{3} \mathrm{O}_{12} \Leftrightarrow[\mathrm{Mg} ; \mathrm{Fe}]_{2} \mathrm{Si}_{2} \mathrm{O}_{6}+\mathrm{CaMgSi}_{2} \mathrm{O}_{6}+[\mathrm{Mg} ; \mathrm{Fe}](\mathrm{Al} ; \mathrm{Cr})_{2} \mathrm{O}_{4 .} .(1)$ 
The aforementioned reaction is used by Godard and Martin (2000) to explain the origin of spinelbearing symplectite around garnet (i.e in garnet peridotite from both UHPM terrenes and kimbelite xenolith). (Nida, 1984) concluded that the Cpx-Opx-Splsymplecite is produced by breakdown of Al-orthopyroxene.

$\mathrm{Al}-\mathrm{Opx} \Leftrightarrow \mathrm{Cpx}+\mathrm{Opx}+$ Spl. (2)

However the observed cluster of Cpx-Opx-Spl from the Pauzalherzolite is far to be interpretated as symplecite rather than it is the crystallographic control exsolution intergrowth related decompression. The absence of garnet in association with Opx-Cpx-Spl cluster suggests the complete transition to the right side of the reaction 1 . However we observed pyrope richgarnet as exsolution lamellae along the cleavage of coarse euhedralCpx in the same thin section. This could suggest that the garnet could be dominated phase prior to decompression. The garnet exsolution from pyroxene is considered to be a result of unmixing of Ca-poor and Al-rich pyroxene due to changes in temperature and pressure (Sautter and Harte, 1988). Compositional evolution and mass balance calculations on the host pyroxene and their exsolutions suggest that an original Al-rich pyroxene with high $\mathrm{Ca}-$, $\mathrm{Mg}$ - and/or Fe-Tschermak components was destabilized in favour of Al-poor pyroxene with secondary garnet.

The inclusion minerals equilibrate with the host porphyroblast and represent frozen equilibrium states (Spear, 1993). For example zircon in ultra-high pressure rocks of the Kokchetavterrane, in which inclusions change from the low pressure phases quartz, albite and graphite in the core domain, to the high pressure phase jadeite in the inner zone, and further to an ultra-high pressure assemblage of jadeite, coesite and diamond in the mantle domain and, to a LP assemblage of quartz, plagioclase and graphite in the outer rim, revealing a $\mathrm{P}-\mathrm{T}$ path from subduction to subsequent exhumation (Parkinson et al., 2002). As a consequence, inclusions are snapshots of local equilibrium between inclusion and host porphyroblast, which, together with compositional changes from the core to rim of the porphyroblast, provide access to the $\mathrm{P}-\mathrm{T}$ paths travelled by a metamorphic rock. However, it is important to distinguish mineral inclusions entrapped during porphyroblast growth and secondary minerals produced by reactions after entrapment in the porphyroblast during decompression and cooling.

The chemical homogeneity of the orthopyroxene and coexisting lamellae of clinopyroxene and spinel suggests that they are represent frozen equilibrium states and thus suitable for estimation of their formation conditions. Equilibrium temperature $1300-1350{ }^{\circ} \mathrm{C}$ was obtained by calibration of the two pyroxene thermometer of Bery and Köhler (1990). Using Putika, 2008 Excel sheet for Two-Pyroxene-based Thermometers . Calculating all the iron as $\mathrm{Fe}^{+2}$. The clinopyroxene barometer of Nimis and Ulmer (1998) gave the pressure range from 2.5-3 GPa.

The obtained pressure and temperature conditions suggest that the association of othopyroxene-clinopyroxene-spinel was stable at the depth of $120 \mathrm{~km}$. The depth corresponds to the lower end of temperature range of mantle peridotite. This suggests that the orthopyroxene with both spinel and clinopyroxene lamellae in the Pauazharzburgite was the early deep assemblages in the kinematic history of the Pauza massif and they are not in equilibrium with the matrix minerals. Similar orthopyroxenes with spinel lamellae observed in spinel lherzolite from kimberlite pipe (Grégoire et al., 2005) and garnet peridotite (Song et al., 2004) 


\subsection{Multiform $\mathrm{Cr}$-spinel inclusion in olivine}

The following five constrains are considered to understand the mechanism of multiform $\mathrm{Cr}$ spinel in olivine.

1- The spinel lamellae with parallel alignment are found in both neoblastic olivine and orthopyroxene

2- Spinel inclusions in olivine have higher $\mathrm{Cr} \#$ and $\mathrm{Fe}^{+3}$ contents in comparison with spinel lamellae in adjacent orthopyroxene (Fig. 8).

3- Olivine with multi-form chromian-spinel inclusions are of higher $\mathrm{Mg}$ content than matrix olivine.(Fig.9)

4- Spinel lamellae in neoblastic olivine and adjacent orthopyroxene have a similar orientation (Fig. 3D).

5- Cr-spinel inclusions in neoblastic olivine have higher contents of $\mathrm{SiO}_{2}$ than that in orthopyroxene (Table 1). An enrichment of $\mathrm{SiO}_{2}$ in spinel lamellae in olivine relative to that in orthopyroxene suggests that the silica that produced by melting of orthopyroxene $\left(2 \mathrm{MgSiO}_{3}=\mathrm{Mg}_{2} \mathrm{SiO}_{4}+\mathrm{SiO}_{2}\right)$ is partly taken in spinel exsolution lamellae structure. However the possibility of contamination of $\mathrm{SiO}_{2}$ is possible

The above five constrains point out that olivine with $\mathrm{Cr}$-spinel multiform was formed by melting of Cr-spinel-rich orthopyroxene.

Fig-8. Ternary plot of the trivalent cations $\mathrm{Cr}, \mathrm{Al}, \mathrm{Fe}^{3+}$ contents of the spinels from lherzolite of the Pauzaultrmafic massif.

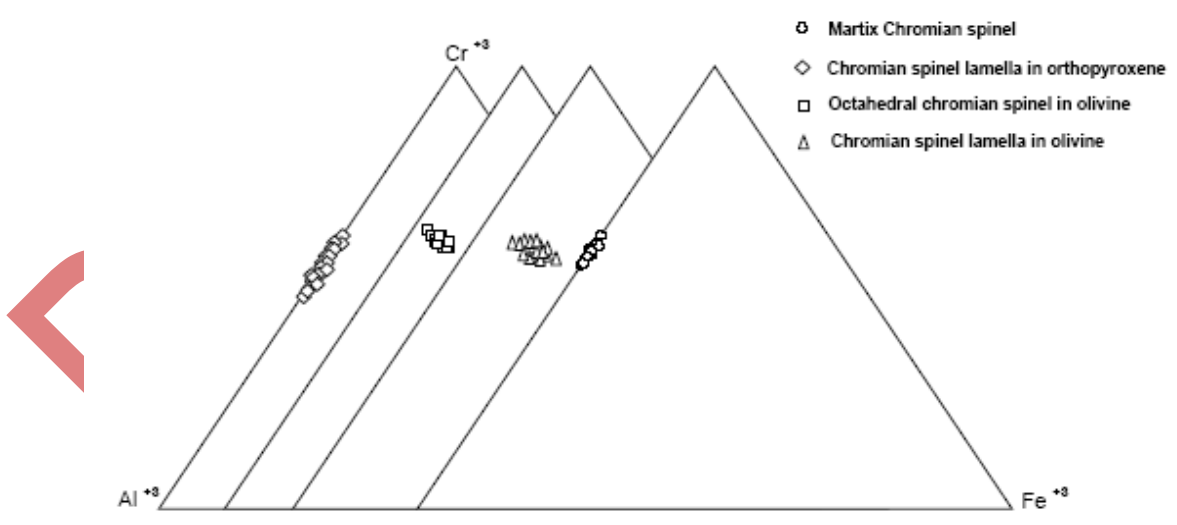

\subsection{Olivine-Spinel Geothermometry.}

For evaluation of the Cr-spinel lamella and host olivine pair in addition to matrix spinel and olivine temperature we have opted to use the formulation of Fabries (1979), mainly because of its straightforward to apply and because temperature calculated by this method are consist with those deduced empirically by Evans and Frost (1975). Furthermore as noted by Fabries et al. (1987), this formulation gives internally consistent temperatures of equilibration. Based on the 
formulation of Fabries (1979), matrix spinel equilibrated with mantle olivine at about $600{ }^{\circ} \mathrm{C}$, whereas mutltiform $\mathrm{Cr}$ - spinel lamellae inclusions equilibrated with host olivine at about $450{ }^{\circ} \mathrm{C}$

Fig-9.Cr\# in spinel vs. Fo content of olivine in lherzolite from Pauzaultrmafic rocks.

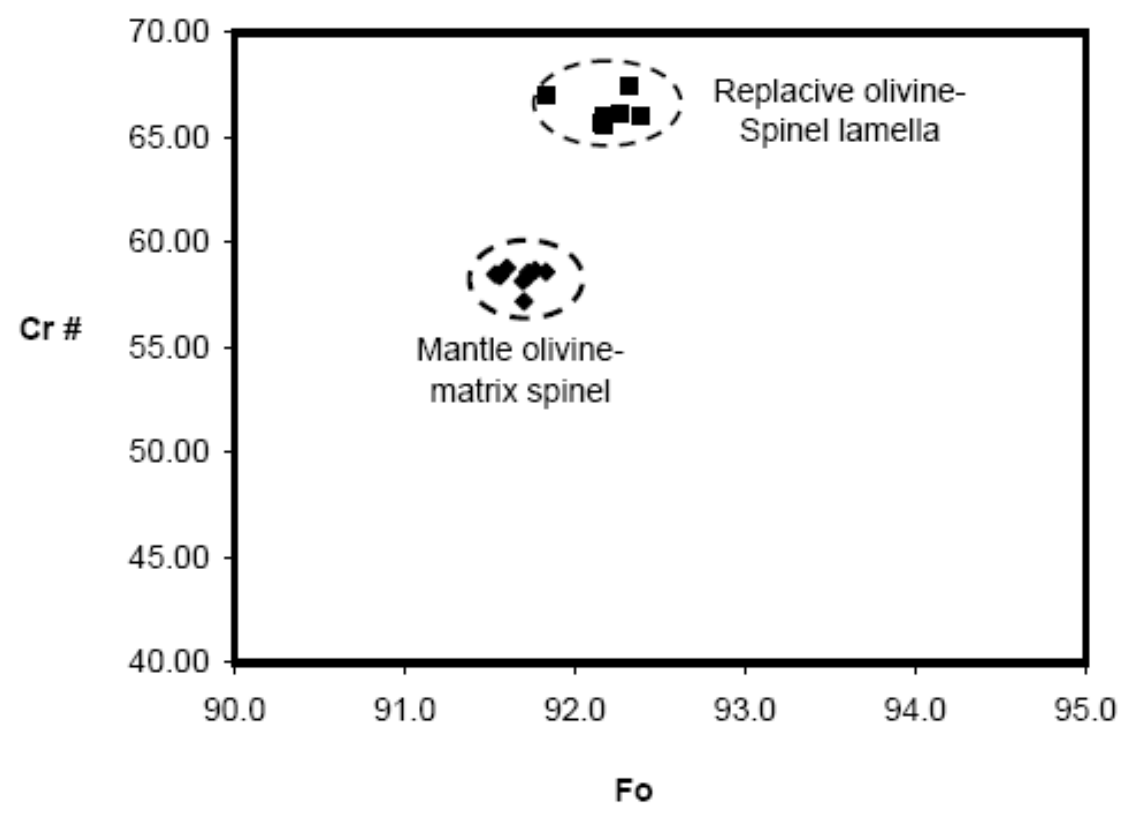

\section{CONCLUSIONS}

1. On the basis of the data presented her we can conclude that the Pauza ultramafic massif consists mainly of harzburgite with small amount of garnet lherzolite.

2. Exsolution from Opx: Some Opx + Cpx + Spsymplectites, without any relics of garnet, have been considered as resulting from decomposition of a former pyrope rich peridoite

3. Two groups of olivines in lherzolite are observed. One was formed in the mantle at the early stageof crystallization history of Pauza massif and the other is neoblastic one, formed by melting of orthopyroxene

Spinel in lherzolite is either occurs either as subhedral grains in the matrix or as multiform inclusion in neoblastic olivine and orthopyroxene. Matrix spinel equilibrated with mantle olivine at about $600{ }^{\circ} \mathrm{C}$, where as spinel lamellae/ and octahedral inclusions equilibrated with replacive olivine at about $450{ }^{\circ} \mathrm{C}$. The orthopyroxene-clinopyroxene-spinel cluster represents deep mantle condition of about $120 \mathrm{~km}$ depth, presenting the early crystallized phase that formed in the kinematic history of the harzburgite in the Pauza massif.

5. Neoblastic olivine of shallow depth origin, and formed by the melting of orthopyroxene with spinel lamellae. As the pressure decrease the solubility of orthopyroxene increase, therefore ascending melt dissolve pyroxene along the rims and priciptate olivine with multifrom chromian-spinel

6. In combination the new data suggests that the $\mathrm{Cr}$-spinel in olivine are inherited from preexisting Cr-spinel-rich othopyroxene as a result of melting by the aid of hydrous silica melt. 
7. Subhedral matrix $\mathrm{Cr}$-spinel equilibrated with the primary olivine at $600 \pm 50^{\circ} \mathrm{C}$, whereas secondary replacive olivine-spinel lamellae pairs were equilibrated at $450 \pm 50{ }^{\circ} \mathrm{C}$. These results suggest that the replacive olivine-Cr-spinel lamellae were formed relatively late in the kinematic history of lherzolite in the Pauza massif.

Funding: This study received no specific financial support.

Competing Interests: The authors declare that they have no competing interests.

Contributors/Acknowledgement: All authors contributed equally to the conception and design of the study. We are very grateful to Mr. Fatah Rahmman for their help during samples collection, as well as the people in Pauza village are highly appreciated for their helps during our stay in the Pauza. Financial support provided by Ministry of Higher Education and Scientific Research of Kurdistan Regional Government.

\section{REFERENCES}

Aswad, K.J. and E.M. Elias,1988. Petrogenesis, geochemistry and metamorphism of spilitized subvolcanic rocks of the Mawat ophiolite complex, Northeastern Iraq. Ofioliti, 13: 95-109.

Aziz, N.H., K.J. Aswad and H.A. Koyi, 2011. Contrasting setting of serpentinite bodies in Northwestern Zagros suture zone, Kurdistan region, Iraq: Tracing subduction signature in serpentinite-matrix mélanges. Geological Magazine, 148 (5-6): 819-837.DOI:org/10.1017/So016756811000409.

Berberian, F., I.D.R. Muir, J. Pankhurst and M. Berberian,1982. Late cretaceous and early miocene andeantype plutonic activity in Northern Makran and central Iran. Journal of Geological Society of London, 139(5): 605-614. DOI:10.1144/gsjgs.139.5.0605.

Bery, G.P. and T. Köhler 1990. Geothermobarometery in four-phase lherzolite. Parii: New thermobarometer, and practical assessment of the existing thermobarometer. Journal of Petrology, 31(6): 1353-1378. DOI: $10.1093 /$ petrology/31.6.1353.

Coleman, R.G., D.E. Lee, L.B. Beatty and W.W. Brannock, 1965. Eclogites and eclogites-their differences and similarities. Geological Society of America Bulletin, 76 (5): 483-508. DOI: 10.1130/00167606(1965) 76[483:ЕAETDA]2.0.CO;2.

Evans, B.W., 1977. Metamorphism of alpine peridotite and serpentinite. Annual Review of Earth and Planetary Sciences, 5: 397-447. DOI: 10.1146/annurev.ea.05.050177.002145.

Evans, B.W. and B.R. Frost, 1975. Chrome-spinel in progressive metamorphism—a preliminary analysis. Geochimica et Cosmochimica Acta 39(6): 959-972. DOI:10.1016/00 16-7037(75)90041-1.

Fabries, J., 1979. Spinel-olivine geothermometry in peridotite from ultramafic complexs. Contribution to Mineralogy and Petrology, 69(4): 329-336. DIO: 10.1007/BFo0372258.

Fabries, J., O. Figueroa and J.P. Lorland, 1987. Petrology and thermal history of highly deformed mantle xenolith from the monferrier basanite, langdoc, Southern France: A comparison with ultamafic complexs from the north pyrenean zone. Journal of Petrology, 28(5): 887-920. DOI: 10.1093/petrology/28.5.887.

Franz, L. and R. Wirth, 2000. Spinel inclusion in olivine of peridotite xenoliths from TABAF seamount (Bismarck Archipelago/ Papua New Guinea): Evidence of the thermal and tectonic evolution of the oceanic lithosphere. Contribution to Mineralogy and Petrology, 140(3): 283-295. DIO.10.1007/s004100000188. 
Godard, G. and S. Martin, 2000. Petrogenesis of kelyphites in garnet peridotites: A case study from the ulten zone, IIalian Alps. Journal of Geodynamics, 3O(1-2): 117-145. DOI.org/10.1016/So2643707(99)00030-7.

Grégoire, M., C. Tinguly, D.R. Bell and A.P. Le Roex, 2005. Spinel iherzolite xenolith from the premier kimberlite ( Kaapvaal Craton, Souh Africa): Nature and Evolution of Shallow Mantle Beneath the Bushveld Complex. Lithos, 84(3-4): 185-205. DOI.org/10.1016/j.lithos.2005.02.004.

Hamasalh, F.R., 2004. Petrochemistry, petrogenesis and tectonic setting of the pauza ultramafic rocks-bulfat complex Nort-East Iraq, Kurdistan region, MSc. Thesis, University of Sulaimani. pp: 115.

Kretz, R., 1983. Symbols of rock-forming minerals. American Mineralogist, 68(1-2): 277-279.

Kubo, K., 2002. Dunite formation process in highly depleted peridotite: Case study of the Iwandake Peridotite, Hokkaido, Japan. Journal of Petrology, 43(3): 423-448. DOI: $10.1093 /$ petrology/43.3.423.

Nida, K., 1984. Petrology of the horoman ultramafic rocks in the hidaka metamorphic belt, Hokkaido, Japan. Jour. Fac., Sci., Hok kaido Univ., 2 1: 197-250.

Nimis, P. and P. Ulmer, 1998. Clinopyroxene geobarometery of magmatic rock. 1. An expanded structural for anhydrous and hydrous, basic and ultrabasic system. Contribution to Mineralogy and Petrology, 133(1-2): 314-327. DIO.10.1007/s004100050442.

Parkinson, C.D., I. Katayama, J.G. Liou and Maruyama, 2002. The diamond-bearing kokchetav massif of kazakhstan: Petrochemistry and tectonic evolution of an unique ultra-high pressure metamorphic terrane. University Tokyo Academic Press. pp: 527.

Rico, L.E., J. Braud and J.H. Brunn, 1977. Le zagros.Mém.Hors-sér.Soc. Géol. Fr., 8: 33-52.

Sautter, V. and B. Harte, 1988. Diffusion gradients in an eclogite xenolith from the roberts victor kimberlite pipe: 1. Mechanism and evolution of garnet exsolution in $\mathrm{Al}_{2} \mathrm{O}_{3}$-rich clinopyroxene. Journal of Petrology 29(6): 1825-1352. DOI 10.1007/BFO0306530.

Song, S., L. Zhang and Y. Niu, 2004. Ultra-deep origin of garnet peridotite from the North Qaidam ultrahigh-pressure belt, Northern Tibetan Plateau, NW China. American Mineralogist, 89(8-9): $1330-1336$.

Song, S.G., L. Su, Y. Niu, G.B. Zhang and L.F. Zhang, 2009b. Two types of peridotite in North Qaidam UHPM belt and their tectonic implications for oceanic and continental subduction: A review. Journal of Asian Earth Science, 35(3-4): 285-297. DOI.org/10.1016/j.jseaes.2008.1 1.009.

Spear, F.S., 1993. Metamorphic phase equilibria and pressure-temperaturetime paths. Washington, DC: Mineralogical Society of America, P 799.

Zhang, H., M.A. Menzies, J.J. Gurney and X. Zhou, 2001. Cratonic peridotite and silica-rich melts: Diopsideenstatite relationships in polymict xenoliths, Kaapvaal, South Africa. Geochimica Cosmochimica Acta, 65(19): 3365-3377. DOI.org/10.1016/S0016-7037(01)00675-5. 